\title{
INCIDENCE OF TAXATION ON THE ECONOMIC AND FINANCIAL SITUATION OF FARMS IN THE EUROPEAN UNION
}

\author{
Joanna Średzińska ${ }^{1 凶}$, Agnieszka Kozera $^{1}$, Aldona Standar ${ }^{1}$ \\ ${ }^{1}$ Poznań University of Life Sciences, Poland
}

\begin{abstract}
In EU countries, agricultural taxation is of major importance for the competitiveness of economic operators active in the agriculture sector. In many countries, the implementation of non-fiscal objectives plays an essential role in preferential tax regimes targeted at the agricultural sector. This is because the adopted tax regime concept impacts the targets, structure and intensification of agricultural production and, as a consequence, affects the economic and financial performance of farms and other aspects. The main purpose of this paper was to assess the economic and financial standing of farms in European Union countries subject to different tax burdens. The empirical study was composed of two stages. The first stage was a synthetic assessment of farm taxation levels in the EU. For that purpose, TOPSIS (Technique for Order Preference by Similarity to an Ideal Solution) was used to develop a synthetic indicator used as a basis to arrange the countries and identify the types of farm taxation levels. The types of EU countries grouped by farm taxation levels became the starting point for an analysis of the relationship between taxation and the farms' economic and financial situation. The sub-indicators of the farms' economic and financial situation were presented for the typological classes concerned, including sub-indicators of production potential, production intensity, incomes, farm subsidies, indebtedness and investments. The empirical study was based on 2013-2015 FADN data (average figures).
\end{abstract}

Keywords: taxes, farms, economic and financial situation, European Union, FADN, TOPSIS

\section{INTRODUCTION}

Just like any other sector of the economy, agriculture is subject to taxation. Farm taxes include income taxes (including the personal income tax and corporate income tax), taxes on wealth (including the property tax charged on land and buildings, inheritance and gift tax and sales tax), and indirect taxes (primarily including VAT) (Przygodzka, 2006, p. 207). According to Khan (2001), farm taxes also include social security contributions. Polish farms are exempt from income tax (except for specific production sectors); the main fiscal burden imposed on them is the agricultural tax (Forfa, 2011, p. 89). Therefore, the Polish agricultural tax regime considerably differs from those adopted in other European Union (EU) states and in OECD countries (cf. Hill and Blandford, 2007; Veen et al., 2007). As emphasized by Girdžiūté and Slavickiené (2011) and Besuspariene (2017), agriculture has a number of particularities (e.g. seasonal nature of the work, state interventionism, dependence on environmental conditions) which make it stand apart from other types of business. As shown in research by Chikwama (2014) and Gollin et al. (2002), the agricultural sector is considered to be a key contributor to economic growth. These two aspects result in various political decisions being made around the world regarding different types of farming taxation. Engen and Skinner (1996) and Myles (2009)

$\bowtie$ Joanna Średzińska, PhD, Department of Economics and Economic Policy in Agribusiness, Poznań University of Life Sciences,
Wojska Polskiego 28 St., 60-637 Poznań, Poland, e-mail: sredzinska@up.poznan.pl, https://orcid.org/0000-0002-1 $189-8456$ 
believe that a strict relationship exists between the fiscal systems in place and economic growth rates at national level. According to Wasilewski and Gruziel (2008, p. 61), tax regimes of EU states are generally based on the income tax, usually paid as a lump sum. While taxes may differ by rate or relief type, all member states share a common principle: agricultural incomes are not exempt from taxation (Kisiel and Idźkowska, 2014, p. 65). Ogrodnik (2009, p. 92) identifies two main agricultural tax regimes. The first one is a general regime where the agricultural sector is subject to the same fiscal regulations as other professionals. It comprises two sub-regimes: the one with no agricultural support instruments (e.g. the case of Finland) and the one based on such solutions as investment incentives (e.g. in the Netherlands, Spain, Belgium UK, Ireland, Denmark, Sweden, Slovakia). In turn, the other tax regime is underpinned by separate preferential fiscal regulations for farmers (as it is the case e.g. in Austria, Germany, France, Poland) (Ogrodnik, 2009, p. 93) 1 .

Note that farm taxation is important from both the economic and social perspectives (Foti et al., 2013). On the one hand, taxation affects the farmer's benefits but on the other, it counteracts poverty in the society which is a matter of extreme importance in developing countries. According to Besuspariene (2017), "properly adjusted taxation systems can contribute to the aims of guaranteeing food and its safety; however, improperly established tax reliefs or other taxation instruments cannot assure value-added agricultural business or possible benefits for the consumers".

Because of its important economic role, the agricultural sector is often subject to a more lenient tax policy (Mądra, 2009, p. 176; Hill and Blandford, 2007). In the relevant literature, that approach is referred to as 'agricultural tax expenditures' (TEs) (Dziemianowicz and Budlewska, 2014, p. 44). Preferential regulations are usually applicable to the taxation of incomes, capital gains or consumption. Dedicated tax regimes are based on lump sum payments and estimations of taxable income. Also, some of them rely on a simplified accounting regime (Kulawik et al., 2013, p. 20). As emphasized by Bieluk (2015, p. 347), various methods of income estimation are particularly popular in the agricultural

${ }^{1}$ Tax reliefs for farmers have some specific consequences which are rarely analyzed. Examples include research by Hanson and Eidman (1985). sector. They are generally believed to reduce the amount of taxes compared to non-farming activities. As indicated by Kulawik et al. (2013, p. 19), tax regimes are determined by historical background, socio-economic changes and the government's agricultural policy. Wasilewski and Ganc $(2012$, p. 7) add that the reason for the agricultural sector's fiscal separation lies in its strategic importance to many European countries. A dedicated tax regime is supposed to protect them against potential problems affecting the agriculture sector and to drive the competitiveness of national farms. Note that the tax regime concept impacts the farming business; according to Forfa (2011, p. 89, after: Hanusz, 1996, p. 260), aspects affected by the tax regime include: production lines and structure, location and intensification of agricultural production, and increased use of basic agricultural productive inputs.

The main purpose of this paper is to assess the economic and financial standing of farms in European Union countries subject to different tax burdens. The empirical study was based on 2013-2015 FADN $^{3}$ data.

\section{RESEARCH METHODS}

The research was conducted in two steps to identify the relationships between taxation levels and the economic and financial situation of farms in EU countries. The first stage was a synthetic assessment of farm taxation levels in the EU. For that purpose, TOPSIS (Technique for Order Preference by Similarity to an Ideal Solution) was used to develop a synthetic indicator. TOPSIS is a method based on the Hellwig's (1972) idea of constructing a synthetic feature. It enables a synthetic assessment of a phenomenon characterized by multiple simple features (see Wysocki, 2010).

The synthetic feature of farm taxation in EU countries was developed in the following steps:

Step 1. Selecting simple features (determinants of farm taxation) for the study.

Step 2. Normalizing the values of simple features with the use of the zero unitarization procedure based on the following formulas:

${ }^{2}$ The empirical study was based on average figures from 2013-2015.

${ }^{3} \mathrm{http}: / /$ ec.europa.eu/agriculture/rica/database/database en.cfm (accessed on December 11, 2017; February 15, 2018). 
$z_{i k}=\frac{x_{i k}-\min \left\{x_{i k}\right\}}{\max \left\{x_{i k}\right\}-\min \left\{x_{i k}\right\}} \quad$ for factors with a stimu-

lating effect; and $\quad z_{i k}=\frac{\max \left\{x_{i k}\right\}-x_{i k}}{\max \left\{x_{i k}\right\}-\min \left\{x_{i k}\right\}} \quad$ for fac-

tors with a restrictive effect;

with:

$x_{i k}-$ value of feature $k$ for object (country) $i$

$\min \left\{x_{i k}\right\}$ - minimum value for feature $k$

$\max \left\{x_{i k}\right\}$ - maximum value for feature $k$

Step 3. Determining the positive ideal development solution $\left(A^{+}\right)$and the negative ideal development solution $\left(A^{-}\right)$as follows:

$$
\begin{gathered}
A^{+}=\left(\max _{i}\left(z_{i 1}\right), \max _{i}\left(z_{i 2}\right), \ldots, \max _{i}\left(z_{i \mathrm{~K}}\right)\right)=\left(z_{1}^{+}, z_{2}^{+}, \ldots, z_{K}^{+}\right) \\
A^{-}=\left(\min _{i}\left(z_{i 1}\right), \min _{i}\left(z_{i 2}\right), \ldots, \min _{i}\left(z_{i K}\right)\right)=\left(z_{1}^{-}, z_{2}^{-}, \ldots, z_{K}^{-}\right)
\end{gathered}
$$

Step 4. For each object (country) considered, calculating the Euclidean distances from the positive ideal solution $\left(d^{+}\right)$and the negative ideal solution $\left(d^{-}\right)$as follows:

$$
d^{+}=\sqrt{\sum_{k=1}^{N}\left(z_{i k}-z_{k}^{+}\right)^{2}}, \quad d^{-}=\sqrt{\sum_{k=1}^{N}\left(z_{i k}-z_{k}^{-}\right)^{2}}
$$

Step 5. Developing the synthetic indicator as per the following formula:

$$
S_{i}=\frac{d_{i}^{-}}{d_{i}^{+}-d_{i}^{-}}
$$

with:

$0 \leq S_{i} \leq 1, i=1,2, \ldots, N$

Based on substantive grounds, the first step of the synthetic feature development procedure resulted in identifying and characterizing a set of simple features which determine the farm taxation level:

$x_{1}-$ taxes $^{4}$ per farming area (EUR/ha), a factor with a stimulating effect;

${ }^{4}$ The indicators listed above were based on FADN SE390, defined as "Farm taxes and other dues (not including VAT and the personal taxes of the holder) and taxes and other charges on land and buildings. Subsidies on taxes are deducted." (Wyniki standardowe..., 2016, p. 28) $x_{2}$ - taxes to total farm labor inputs $\left(\mathrm{EUR} / \mathrm{AWU}^{5}\right)$, a factor with a stimulating effect;

$x_{3}$ - taxes to total farm assets (EUR/EUR 1,000 worth of assets), a factor with a stimulating effect.

The set of simple characteristics established based on substantive grounds was subject to further statistical verification to determine their information capacity (correlation with other characteristics) and discriminatory capacity (i.e. variability across the objects considered). The following was analyzed: the coefficients of variation of the features; and the diagonal entries of the inverse of the matrix of correlation coefficients between the features. Based on the results, all of the features were retained. The second step of the procedure consisted in normalizing the values of simple features with the use of the zero unitarization procedure. The features under consideration were found to have a stimulating effect on farm taxation levels. Afterwards, the positive ideal development solution and negative ideal development solution were determined (step 3), and the Euclidean distances from model units were calculated for each country considered (step 4). The last (fifth) step consisted in using TOPSIS to develop the synthetic feature based on estimated Euclidean distances. Based on the identified values of the synthetic indicator, the countries under consideration were ordered by level of farm taxation. On these grounds, EU countries were grouped into typological classes by farm taxation level with the use of a statistical method (based on the mean $(\bar{S})$ and standard deviation $\left(s_{s}\right)$ values of the synthetic indicator) (cf. Wysocki 2010):

\begin{tabular}{ll}
\hline class 1 (very high) & $S_{i} \geq \bar{S}+s_{s}$ \\
class 2 (medium high) & $\bar{S} \leq S_{i}<+\bar{S}+s_{s}$ \\
class 3 (medium low) & $\bar{S}-S_{s} \leq S_{i}<\overline{\mathrm{S}}$ \\
class 4 (low) & $S_{i}<\bar{S}-s_{s}$ \\
\hline
\end{tabular}

The types of EU countries grouped by farm taxation levels became the starting point for an analysis of the relationship between taxation and the farms' economic and financial situation. The sub-indicators of the farms' economic and financial situation were presented for the typological classes concerned, including sub-indicators

${ }^{5}$ The Annual Work Unit is equivalent to 2120 working hours per year (Wyniki standardowe..., 2016, p. 4, 7). 
Table 1. Classification of European Union states by farm taxation levels

\begin{tabular}{|c|c|c|c|c|}
\hline $\begin{array}{l}\text { Thresholds for the } \\
\text { synthetic indicator }\end{array}$ & $\begin{array}{l}\text { Typological } \\
\text { class }\end{array}$ & $\begin{array}{l}\text { Farm taxation } \\
\text { level }\end{array}$ & $\begin{array}{c}\text { Countries } \\
\text { (values of the synthetic indicator) }\end{array}$ & $\begin{array}{l}\text { Percentage of } \\
\text { countries } \\
(\%)\end{array}$ \\
\hline$(0.466,0.730>$ & 1 & high & $\begin{array}{l}\text { Italy (0.730), Netherlands (0.597), Denmark (0.538), France } \\
(0.474)\end{array}$ & 15.4 \\
\hline$(0.279,0.466>$ & 2 & medium high & $\begin{array}{l}\text { Slovakia (0.454), Belgium }(0.439) \text {, Germany }(0.430) \text {, Croatia } \\
(0.384) \text {, Romania }(0.369) \text {, Hungary }(0.325) \text {, Austria }(0.309) \text {, } \\
\text { Latvia }(0.308)\end{array}$ & 30.7 \\
\hline$(0.093,0.279>$ & 3 & medium low & $\begin{array}{l}\text { Bulgaria (0.235), Czech Republic }(0.223) \text {, Poland }(0.219) \text {, } \\
\text { Finland (0.187), Luxembourg }(0.184) \text {, Spain }(0.170) \text {, Portugal } \\
(0.166) \text {, Estonia (0.139), Greece }(0.133) \text {, United Kingdom } \\
(0.096)\end{array}$ & 38.5 \\
\hline$(0.000,0.093>$ & 4 & low & $\begin{array}{l}\text { Lithuania (0.080), Ireland (0.041), Sweden (0.017), Slovenia } \\
(0.015)\end{array}$ & 15.4 \\
\hline
\end{tabular}

Source: own calculations and elaboration based on FADN data (accessed on December 11, 2017).

of production potential, production intensity, incomes, farm subsidies, indebtedness and investments.

\section{RESULTS OF EMPIRICAL STUDIES}

Table 1 shows the classification of EU farms by taxation level. The first typological class, demonstrating the highest level of taxation, includes Italian, Dutch, Danish and French farms. Depending on the country, the following is used as the tax base: income from agricultural land (in Italy); income from an agricultural or forestry undertaking (in the Netherlands and Denmark); income from arable land and agricultural or forestry undertakings (in France) (Kulawik et al., 2013, p. 124). The distinctive feature of Italian agriculture is that income is calculated on a lump-sum basis. There are numerous exemptions applicable to many areas, just like in France where preferential regimes extend to incomes, reliefs, inheritances, capital gains and indirect taxes (Kulawik et al., 2013, p. 20). For instance, in the Netherlands, incomes may be specified based on average figures; moreover, investment incentives and accelerated depreciation options are in place. As regards Denmark, incomes are determined based on a business plan, and small farms are subject to non-standard taxation (Kulawik et al., 2013, p. 16).

As shown by data in Table 2, in 2013-2015, farms falling within the first typology class reported nearly EUR 80 of taxes per hectare of agricultural land, which is over EUR 1,640 per full-time equivalent (FTE) and EUR 3.3 per EUR 1,000 worth of assets. The economic strength of these operators (an average economic size nearly four times higher than the Union average level) sets them apart from other groups. Also, they had a relatively large area of agricultural land (over $60 \mathrm{ha}$, on average) and relied on large quantities of labor (nearly 2 AWU). This was accompanied by a wide availability of technical assets, measured as the ratio of fixed assets per FTE (over EUR 612,000 compared to the EU average level of EUR 177,000). The first typology class was also characterized by high levels of production intensity. Expenditure on current assets, measured by intermediate consumption per hectare of agricultural land, went beyond EUR 2,260, whereas fixed capital consumption, measured by depreciation per hectare, was in excess of EUR 416. Note that with a production profitability rate (the ratio of production value to total costs) beyond $100 \%$, these farms were rather efficient, especially compared to other typological classes. At the same time, the total share of operating and investments subsidies in the family farming income was ca. $60 \%$. Compared to other typological classes and to the Union average level (above 90\%), this is a relatively small percentage which suggests these farms would perform well even without subsidies. The above is corroborated by both the labor productivity level and the own (unpaid) labor profitability rate, exceeding by several times the corresponding 
figures observed in other typological classes. The distance between that group and other ones was even more evident upon deduction of the balance of operating and investment subsidies and taxes ${ }^{6}$. Another characteristic feature of that group was their high indebtedness. The reported share of debts in total liabilities was nearly $38 \%$, reaching the highest level of all typological classes identified. Note also the large amount of gross investments per hectare of agricultural land (nearly EUR 480, compared to the average Union level of ca. EUR 230). The scale of net investments was less significant which could be explained by large amounts of fixed assets and consequent high depreciation.

The second group ( $2^{\text {nd }}$ typological class) includes farms subject to a medium high taxation level located in eight countries: Slovakia, Belgium, Germany, Croatia, Romania, Hungary, Austria and Latvia (Table 1). For instance, the Belgian and Austrian agricultural tax regimes are based on preferential measures for both income taxes and indirect taxes. Much more favorable regulations are offered by the German tax regime which includes preferential provisions for the inheritance tax and other allowances as a part of social security for farmers. Nonetheless, Germany applies the highest tax rates of all Union countries and is believed to have one of the most complicated tax regimes across Europe. In that group, Hungarian farmers are the only ones to enjoy lower taxes on profits and lower indirect taxes (Kisiel and Idźkowska, 2014, p. 68; Kulawik et al., 2013, p. 20).

While demonstrating a significantly smaller economic size, farms included in the $2^{\text {nd }}$ typology class were only slightly smaller in physical terms (with an average area of agricultural land beyond 50 ha in the study period) than class 1 farms. Although they reported the same levels of labor inputs, they could provide their employees with much less technical equipment than class 1 farms. They relied on relatively extensive farming systems. Intermediate consumption per hectare of agricultural land was particularly low, reaching only

${ }^{6}$ This paper uses a methodology proposed by Sobczyński (2010, p. 247-248). In his approach, the labor productivity ratio (measured as net value added per FTE) and the own labor profitability ratio (measured as family farming income per fulltime family employee) was adjusted with the balance of operating and investment subsidies and taxes. In her paper, Kołoszko-Chomentowska (2016, p. 451-452) also took account of subsidies to adjust the results.
EUR 954 (the lowest level of all groups identified). The production profitability rate of $105 \%$ was close to the corresponding value calculated for class 1 farms. However, incomes per FTE and per full-time family employee were several times lower. Given the similar levels of labor inputs, it may be concluded that the considerably larger production scale was a contributing factor driving the effective use thereof in group 1 farms. Compared to class 1 , class 2 farms reported a higher level of subsidies, representing nearly $87 \%$ of incomes. These farms were more conservative in borrowing capital to finance their operations, as reflected by debt ratios of up to $20 \%$. Also, they demonstrated a relatively small scale of investments, with a gross value of ca. EUR 220 per hectare of agricultural land (Table 2).

The third typological class, with a medium low taxation level, proved to be the largest one. It included farms from as many as ten countries, representing almost $40 \%$ of the population surveyed (Table 1). This was the largest set of countries covered by this analysis, characterized by the largest differences in agricultural taxation levels. In Finland, the agricultural sector is subject to the general tax regime and is not provided with any supporting instruments, whereas in Poland a dedicated tax regime is in place to reduce the fiscal burden. There is a broad range of preferential solutions applicable to incomes and other fiscal aspects. Furthermore, the farmers are covered by their own insurance system (Ogrodnik, 2009, p. 108; Kulawik et al., 2013, p. 20).

In class 3 , taxes per hectare of agricultural land were slightly above EUR 10; the ratio of taxes per FTE was EUR 277; there was ca. EUR 1.7 of taxes per EUR 1,000 worth of assets. In terms of economic size and availability of labor and land, these farms were similar to class 2 . At the same time, they demonstrated better proportions between productive inputs employed; both the fixedassets-to-labor and land-to-labor ratios reached higher levels (over EUR 136,000 and nearly 33 ha per AWU, respectively). Nonetheless, in this group, the production value did not fully cover the costs incurred (the production profitability ratio did not exceed $100 \%$ ). While the labor productivity rate (also adjusted with the balance of operating and investment subsidies and taxes) and own labor profitability rate were positive, the adjusted family farming income per full-time family employee was negative. Note the considerable role of Union support for the incomes of these farms, especially the importance of operating subsidies which represented, on average, 
Średzińska, J., Kozera, A., Standar, A. (2019). Incidence of taxation on the economic and financial situation of farms in the European Union. J. Agribus. Rural Dev., 3(53), 257-265. http://dx.doi.org/10.17306/J.JARD.2019.01131

Table 2. Incidence of taxation on the economic and financial situation of farms in the European Union

\begin{tabular}{|c|c|c|c|c|c|}
\hline \multirow{3}{*}{ Specification } & \multicolumn{4}{|c|}{ Typological class - Farm taxation level } & \multirow{3}{*}{ Total } \\
\hline & 1 & 2 & 3 & 4 & \\
\hline & high & medium high & medium low & low & \\
\hline \multicolumn{6}{|c|}{ Farm taxation } \\
\hline Taxes per hectare of agricultural land (EUR/ha) & 79.8 & 26.1 & 10.4 & 3.6 & 13.2 \\
\hline Taxes to total labor inputs (EUR/AWU) & 1643.8 & 472.5 & 277.0 & 92.5 & 351.5 \\
\hline Taxes per EUR 1,000 worth of assets (EUR) & 3.3 & 3.8 & 1.7 & 0.2 & 2.1 \\
\hline \multicolumn{6}{|c|}{ Economic and financial situation of farms } \\
\hline Average economic size of farms (EUR thous.) & 266.7 & 55.9 & 73.0 & 38.8 & 70.0 \\
\hline Average area of agricultural land (ha) & 61.5 & 50.2 & 49.7 & 48.5 & 49.4 \\
\hline Average total labor inputs (AWU) & 1.9 & 1.9 & 1.7 & 1.5 & 1.7 \\
\hline Fixed assets-to-labor ratio (EUR thousand/AWU) & 612.4 & 99.3 & 136.4 & 393.7 & 177.0 \\
\hline Agricultural area per FTE (ha/AWU) & 28.5 & 27.7 & 32.8 & 34.6 & 30.2 \\
\hline $\begin{array}{l}\text { Expenditure on current assets per hectare } \\
\text { of agricultural land (EUR/ha) }\end{array}$ & $2,264.0$ & 954.0 & $1,065.3$ & $1,276.8$ & $1,125.4$ \\
\hline $\begin{array}{l}\text { Fixed capital consumption per hectare } \\
\text { of agricultural land (EUR/ha) }\end{array}$ & 416.2 & 221.6 & 185.6 & 222.7 & 269.9 \\
\hline Production profitability (\%) & 107.0 & 105.0 & 98.0 & 98.0 & 102.5 \\
\hline Net value added per FTE (EUR/AWU) & $42,121.7$ & $16,762.2$ & $18,220.4$ & $16,400.4$ & $20,277.1$ \\
\hline Adjusted net value added per FTE (EUR/AWU) & $35,480.7$ & $6,134.8$ & $4,946.6$ & $5,566.6$ & $6,365.9$ \\
\hline $\begin{array}{l}\text { Family farming income per full-time family } \\
\text { employee (EUR/FWU) }\end{array}$ & $34,623.9$ & $19,035.1$ & $15,357.1$ & $11,585.0$ & $20,319.2$ \\
\hline $\begin{array}{l}\text { Adjusted family farming income per full-time } \\
\text { family employee (EUR/FWU) }\end{array}$ & $13,352.4$ & $3,287.4$ & -9.3 & -497.4 & $2,061.7$ \\
\hline Share of operating subsidies in incomes (\%) & 57.7 & 83.3 & 93.4 & 111.3 & 87.5 \\
\hline Share of investment subsidies in incomes (\%) & 2.4 & 3.6 & 5.6 & 7.7 & 3.6 \\
\hline Debt ratio $(\%)$ & 37.7 & 19.2 & 16.4 & 9.2 & 19.2 \\
\hline $\begin{array}{l}\text { Gross investments per hectare of agricultural land } \\
\text { (EUR/ha) }\end{array}$ & 479.7 & 220.5 & 219.0 & 298.1 & 232.1 \\
\hline $\begin{array}{l}\text { Net investments per hectare of agricultural land } \\
\text { (EUR/ha) }\end{array}$ & 63.5 & 90.8 & 32.9 & 86.5 & 74.8 \\
\hline
\end{tabular}

Source: own calculations and elaboration based on FADN data (accessed on February 15, 2018).

as much as over $93 \%$ of incomes (nearly 6 percentage points above the EU average level). Compared to other groups, these farms were the least inclined to invest and showed a relatively low level of indebtedness (the share of debt in liabilities was ca. 16\%) (Table 2).
The $4^{\text {th }}$ typological class was composed of farms subject to the lowest taxation levels, i.e. those located in Lithuania, Ireland, Sweden and Slovenia (Table 1). Among those listed above, the Irish agricultural tax regime includes many preferential provisions for capital 
gains and inheritances, as well as direct and indirect tax benefits (Kulawik et al., 2013, p. 20).

In the $4^{\text {th }}$ typological class, the amount of taxes per unit of specific productive inputs was several times lower than the EU average level. In economic terms and as regards availability of labor and land, these were the smallest operators of all classes identified. However, they demonstrated very favorable proportions between productive inputs, with EUR 390,000 worth of fixed assets per FTE (compared to the EU average level of EUR 177,000) ${ }^{7}$ and 34 ha of agricultural land per FTE (compared to the Union average level of $30 \mathrm{ha}$ ). These farms also reported rather high levels of production intensity: the expenditure on current assets per hectare was almost EUR 1,277 and the fixed capital consumption per hectare was nearly EUR 223. The production profitability rate (98\%) was the same as in class 3 . However, the labor productivity and own labor profitability ratios were lower (ca. EUR 16,400 and EUR 11,600, respectively). Particular attention should be paid to the adjusted ratio of unpaid labor profitability which, in this class, was negative over the study period. The share of subsidies in the family farming income (over $111 \%$ for operating subsidies and nearly $8 \%$ for investment subsidies) also shows that these operators would be unable to make profits without subsidies. Note also that this group was characterized by low levels of borrowed capital (the debt ratio was ca. 9\%, the lowest value of all groups identified). Meanwhile, the investment scale was relatively large, as reflected by gross investments accounting for nearly EUR 300 per ha, compared to the Union average level of ca. EUR 230 per ha (Table 2).

\section{SUMMARY AND CONCLUSIONS}

The conclusion from this study is that farm taxation considerably differs across European Union countries. The highest tax rates were imposed on Italian, Dutch, Danish and French farms. In turn, the lowest rates were reported in Lithuania, Ireland, Sweden and Slovenia. The groups of countries with medium levels of farm taxation were considerably larger than other ones.

Some patterns were observed based on this study. Lower taxation levels were associated with economically smaller farms, smaller land resources and lower

\footnotetext{
${ }^{7}$ Such a high ratio of fixed assets to labor in that group could result from what is referred to as "overinvestment."
}

labor inputs. Meanwhile, increasingly higher capitalto-labor and land-to-labor ratios were reported when moving up from one class to another (except for the $1^{\text {st }}$ typological class demonstrating the highest level of farm taxation). Nevertheless, the decreasing levels of farm taxation entailed a consistent deterioration in the ratio of production value to costs. Also, lower levels of farm taxation were usually accompanied by lower labor productivity and lower profitability of own labor. This is especially true for the adjusted family farming income per full-time family employee which turned negative in groups with lower taxation levels. The share of subsidies in incomes, which becomes significantly higher when moving up from one group to another, allowed to confirm the major role of EU subsidies in farms subject to lower taxation levels. Therefore, it may be concluded that farms subject to lower taxation levels proved to be less efficient. Another observation is that lower levels of farm taxation were associated with lower levels of debt.

\section{ACKNOWLEDGMENT/SOURCE OF FINANCING}

The project was financed from resources of the National Center for Science, allocated pursuant to decision DEC-2012/05/B/HS4/04134.

\section{REFERENCES}

Besuspariene, E. (2017). Singularity of sustainable taxation in agriculture. In: A. Raupelienè (Ed.), Proceedings of the 8th International Scientific Conference Rural Development 2017, 23-24 November 2017 (pp. 909-916). Kaunas: Aleksandras Stulginskis University.

Bieluk, J. (2015). Obciążenia podatkowe gospodarstw rodzinnych w Polsce i w Europie. Propozycje rozwiązań na przykładzie jednostek prowadzących działalność w zakresie działów specjalnych produkcji rolnej [Taxation of family farms in Poland and Europe. Units conducting special agricultural production as examples of suggested solutions]. In: P. Litwiniuk (Ed.), Prawne mechanizmy wspierania i ochrony rolnictwa rodzinnego $\mathrm{w}$ Polsce $\mathrm{i}$ innych państwach Unii Europejskiej [Legal mechanisms for supporting and protecting family farming in Poland and other European Union countries] (pp. 335-350). Warszawa: Fundacja Programów Pomocy dla Rolnictwa FAPA [in Polish].

Chikwama, C. (2014). Does agriculture play an important role in economic growth and structural transformation. 
Agriculture and growth Agriculture and growth evidence paper series June 2014. London: Department for International Development.

Dziemianowicz, R., Budlewska, R. (2014). Preferencje podatkowe jako instrument polityki rolnej - na przykładzie wybranych państw Unii Europejskiej [Tax expenditures as an instrument of the agriculture policy - an example of selected European Union Member States]. Zesz. Nauk. SGGW Warsz. Probl. Roln. Świat., 14(29), 2, 43-58. Retrieved from: http://www.wne.sggw.pl/czasopisma/pdf/ PRS_2014_T14(29)_z2.pdf [in Polish].

Engen, E. M., Skinner, J. (1996). Taxation and economic growth. Nation. Tax J., 49(4), 617-642.

Forfa, M. (2011). Obciążenie fiskalne gospodarstw rolniczych w zależności od wielkości ekonomicznej oraz typu rolniczego [The level of fi scal burden in farms in relation european size unit and type of farming]. Zesz. Nauk. SGGW Warsz. Ekon. Org. Gosp. Żywn., 92, 89-101. Retrieved from: http:/www.wne.sggw.pl/czasopisma/pdf/ EIOGZ_2011_nr92.pdf [in Polish].

Foti, N. T., Scuderi, A., Timpanaro, G. (2013). Organic social agriculture: a tool for rural development. Retrieved June 20 2019 from: https://www.researchgate.net/profile/Giuseppe_Timpanaro/publication/236615829_Organic_social_agriculture_A_tool_for_rural_development/ links/004635184b6767a13c000000.pdf

Girdžiūté, L., Slavickiené, A. (2011). Agricultural risks and analysis of their evaluation methods. Manag. Theory Stud. Rural Bus. Infr. Dev., 3(27), 66-77.

Gollin, D., Parente, S., Rogerson, R. (2002). The role of agriculture in development. Am. Econ. Rev., 92(2), 160-164.

Hanson, G. D., Eidman, V. R. (1985). Agricultural income tax expenditures - a microeconomic analysis. Am. J. Agric. Econ., 67(2), 271-278.

Hanusz, A. (1996). Polityka podatkowa w zakresie różnicowania obciążeń dochodów rolniczych [Tax policy in the field of diversifying the burden of agricultural income]. Lublin: Wydawnictwo UMCS [in Polish].

Hellwig, Z. (1972). Procedure of evaluating high-level manpower data and typology of countries by means of the taxonomic method. In: Z. Gostkowski (Ed.), Towards a System of Human Resources Indicators for Less Developed Countries: Papers Prepared for a UNESCO Research Project (pp. 115-134). Wrocław: Ossolineum, Polish Academy of Sciences Press.

Hill, B., Blandford, D. (2007). Taxation concessions as instruments of agricultural policy. Paper presented at the annual Agricultural Economics Society Conference. England: University of Reading.

FADN (n.d.). FADN Public Database. Retrieved Dec $11^{\text {th }}$ 2017 from: http://ec.europa.eu/agriculture/rica/database/ database en.cfm, retrieved December 11, 2017; February 15, 2018.

Khan, M. H. (2001). Agricultural taxation in developing countries: a survey of issues and policy. Agric. Econ., 24, 315-328.

Kisiel, R., Idźkowska, K. (2014). System opodatkowania rolnictwa w Polsce oraz w wybranych krajach Unii Europejskiej [The system of agriculture taxation in Poland and chosen countries of the European Union]. Zesz. Nauk. SGGW Warsz. Polit. Eur. Fin. Market., 12(61), 64-78. Retrieved from: http://www.wne.sggw.pl/czasopisma/pdf/ PEFIM_2014_T12_nr61.pdf [in Polish].

Kołoszko-Chomentowska, Z. (2016). Managing sustainable development of agriculture - case of Poland. In: I. Zentková (Ed.), International Scientific Days 2016 The Agri-Food Value Chain: Challenges for Natural Resources Management and Society, May 19-20, 2016 Nitra (pp. 447-454). Slovak Republic, FEM SUA in Nitra. Retrieved from: http://www.slpk.sk/eldo/2016/dl/9788055215037/ files/07/koloszko.pdf

Kulawik, J., Lelong, P.-Y., Pawłowska-Tyszko, J., Soliwoda, M. (2013). Systemy podatkowe w krajach Unii Europejskiej [Tax systems in the European Union]. Warszawa: IERiGŻ-PIB [in Polish].

Mądra, M. (2009). Obciążenia podatkiem rolnym indywidualnych gospodarstw rolnych [The level of agricultural tax burden in individual farms]. Zesz. Nauk. SGGW Warsz. Ekon. Org. Gosp. Żywn., 76, 175-186. Retrieved from: http://www.wne.sggw.pl/czasopisma/pdf/EIOGZ_2009_ nr76.pdf [in Polish].

Myles, G. D. (2009). Economic growth and the role of taxation-disaggregate data. OECD Economic Department Working Papers, 715, from: http://people.exeter.ac.uk/gdmyles/papers/pdfs/OECDfin.pdf

Ogrodnik, D. (2009). Podatek rolny w krajach europejskich [Agricultural tax in European countries]. Zagad. Ekon. Roln., 3, 91-111 [in Polish].

Przygodzka, R. (2006). Fiskalne instrumenty wspierania rozwoju rolnictwa - przyczyny stosowania, mechanizmy i skutki [Fiscal instruments supporting agriculture's development - reasons for use, mechanisms and effects]. Białystok: Wydawnictwo Uniwersytetu w Białymstoku [in Polish].

Sobczyński, T. (2010). Wydajność pracy a poziom wsparcia gospodarstw rolniczych w Polsce na tle UE [Labour productivity versus level of subsidies for Polish farms compared to EU]. Rocz. Nauk Roln., Ser. G, 97(3), 244-257. Retrieved from: http://www.wne.sggw.pl/czasopisma/pdf/ RNR_2010_T97_z3.pdf [in Polish].

Veen,H.B., VanderMeulen,H.A.B., VanderBommel, K.H.M., Doorneweert, B. (2007). Exploring agricultural taxation 
in Europe. Report. Hague: The Agricultural Economics Research Institute.

Wasilewski, M., Ganc, M. (2012). Funkcjonowanie systemu podatkowego $\mathrm{w}$ rolnictwie oraz propozycje zmian w opinii rolników indywidualnych [Taxation in agriculture and proposed changes in the opinion of private farmers]. Fin. Rynki Fin., Ubezp. Zesz. Nauk. Uniw. Szczec., 50(689), 725-733. Retrieved from: http://wneiz.pl/nauka_wneiz/ frfu/50-2012/FRFU-50-725.pdf [in Polish].

Wasilewski, M., Gruziel, K. (2008). Podatek dochodowy $\mathrm{w}$ indywidualnych gospodarstwach rolniczych - koncepcja i skutki [Income tax in individual farms - concept and effects]. Zag. Ekon, Roln., 1, 60-61 [in Polish].
Wyniki Standardowe 2015 uzyskane przez gospodarstwa rolne uczestniczące w Polskim FADN. Część I. Wyniki Standardowe [Standard Results 2015 obtained by agricultural holdings participating in the Polish FADN. Part I. Standard results] (2016). Warszawa: IERiGŻ-PIB. Retrieved from: http://fadn.pl/wp-content/uploads/2015/12/ SRwaz_2015_www.pdf [in Polish].

Wysocki, F. (2010). Metody taksonomiczne w rozpoznawaniu typów ekonomicznych rolnictwa i obszarów wiejskich [Taxonomic methods in recognizing economic types of agriculture and rural areas]. Poznań: Wyd. UPP [in Polish]. 